\title{
KESALAHAN PELAFALAN KOSAKATA DIFTONG DAN BUKAN DIFTONG SISWA BIPA1 DI DAVAO CITY - FILIPINA
}

\author{
Marlia \\ Davao City, Filipina \\ E-mail: marliasuryana@gmail.com
}

\begin{abstract}
BIPA students in Davao City - the Philippines mostly use Visaya in their daily lives. In addition, some of them are still affected by Spanish in the pronounciation of the sounds of the language. This is the main influence of pronounciation errors in Indonesian vocabulary. This research examines the pronunciation of vocabulary with diphthong and not diphthong in Bahasa Indonesia. The purpose of this analysis is to describe the mistakes of BIPA students in pronouncing diphthong double vowels and not diphthongs and to explain the solutions that can be done to minimize these errors. The method used is descriptive qualitative. The finding in this research is that there are errors in vocal pronunciation of double diphthong and not diphthong. As many as 96\% recite the double diphthong correctly and 4\% still pronounce incorrectly. $67 \%$ recite double vowels instead of diphthongs being diphthongs and 33\% recite double vowels separately (read every letter in the final syllable). This happens because of three things. First, the influence of the Visaya language. Second, the influence of Spanish. Third, the presence of allophones in Indonesian vowels. These problems can be overcome in three ways. First, through spoken-syllable techniques. Second, through the technique of imitation. Third, through repeated words. Through this research, it is expected to be able to help BIPA students in reciting Indonesian vocabulary, especially duplicate vocabulary, so that pronunciation errors can be minimized.
\end{abstract}

Keywords: diphthong pronounciation; student BIPA 1; Davao City Philippines

Abstrak: Siswa BIPA di Davao City - Filipina mayoritas menggunakan bahasa Visaya dalam kehidupan sehari-harinya. Selain itu, sebagian di antara mereka masih terpengaruh bahasa Spanyol dalam pelafalan bunyi bahasa. Hal inilah menjadi pengaruh utama kesalahan pelafalan dalam kosa kata bahasa Indonesia. Riset ini mengkaji pelafalan kosa kata bervokal rangkap diftong dan bukan diftong bahasa Indonesia. Tujuan dilakukan analisis ini adalah mendeskripsikan kekeliruan siswa BIPA dalam pelafalan vokal rangkap diftong dan bukan diftong serta memaparkan solusi yang dapat dilakukan untuk meminimalkan kesalahan tersebut. Metode yang digunakan adalah deskriptif kualitatif. Temuan dalam riset ini adalah adanya kekeliruan pelafalan vokal rangkap diftong dan bukan diftong. Sebanyak $96 \%$ melafalkan vokal rangkap diftong dengan benar dan $4 \%$ masih melafalkan salah. Sebanyak $67 \%$ melafalkan vokal rangkap bukan diftong menjadi diftong dan 33\% melafalkan vokal rangkap secara terpisah (dibaca per huruf di silabel akhir). Hal ini terjadi disebabkan oleh tiga hal. Pertama, pengaruh bahasa Visaya. Kedua, pengaruh bahasa Spanyol. Ketiga, adanya alofon dalam vokal rangkap bahasa Indonesia. Masalah-masalah tersebut dapat diatasi melalui tiga cara. Pertama, melalui teknik ucap - silabel. Kedua, melalui teknik ucap - tiru. Ketiga, melalui ucap - ulang. Melalui riset ini, diharapkan dapat membantu siswa BIPA dalam melafalkan kosa kata bahasa Indonesia, terutama kosa kata bervokal rangkap, sehingga kesalahan pelafalan dapat diminimalkan.

Kata Kunci: pelafalan diftong; siswa BIPA 1; Davao City Filipina

Permalink/DOI: http://doi.org/10.15408/dialektika.v6i1.7470 


\section{Pendahuluan}

Setiap negara mengharapkan bahasanya menjadi bahasa internasional, tidak terkecuali Indonesia. Banyak upaya yang dapat dilakukan untuk menginternasionalkan bahasa Indonesia di antaranya melalui pengenalan dan diplomasi kebahasaan kepada orang asing melalui program bahasa Indonesia untuk penutur asing atau yang dikenal dengan istilah BIPA. Program BIPA diselenggarakan oleh beberapa instansi di Indonesia, salah satunya adalah Pusat Pengembangan dan Strategi Diplomasi Kebahasaan (PPSDK) di Sentul-Bogor.

Program BIPA memiliki standar dan capaian tersendiri yang meliputi empat keterampilan berbahasa, yakni membaca, menulis, menyimak, berbicara. Selain keempat keterampilan berbahasa tersebut, siswa BIPA dituntut untuk memahami dan menggunakan tata bahasa Indonesia dengan benar. Kelima komponen tersebut harus dipahami dan dikuasai oleh para siswa. Namun, tidak menutup kemungkinan para siswa seringkali merasa kesulitan untuk memahami dan menguasainya. Salah satu keterampilan yang sulit dikuasai oleh siswa adalah berbicara. Hal ini diperkuat oleh hasil penelitian yang telah dilakukan.

Penelitian sebelumnya terkait kompetensi siswa bipa dalam berbicara telah dilakukan oleh Yohana Vita Desiani, mahasiswa Program Studi Pendidikan Bahasa dan Sastra Indonesia Universitas Sanata Dharma pada tahun 2017 dengan judul penelitian Tingkat Kemampuan Berbicara Pembelajar Asing Level Beginner Menggunakan Tes Teknik Konstruktalog di Wisma Bahasa Yogyakarta'. Simpulan hasil penelitiannya menunjukkan bahwa siswa BIPA level beginner (BIPA 1) mengalami kesulitan berbicara, terutama dalam pengucapan, aksen, dan kelancaran. Selain itu, penelitian lainnya dilakukan oleh Raden Yusuf Sidiq Budiawan dan Rukayati pada tahun 2018 dari Program Studi Pendidikan Bahasa dan Sastra Indonesia PGRI Semarang dengan judul Kesalahan Bahasa dalam Praktik Berbicara Pemelajaran Bahasa Indonesia bagi Penutur Asing (BIPA) di Universitas PGRI Semarang Tahun 2018². Hasil penelitiannya menunjukkan bahwa (1) kesalahan berbahasa, khususnya kemampuan berbicara tersebut dapat diklasifikasikan menjadi lima jenis, yakni kesalahan dalam pelafalan, kesalahan dalam intonasi, kesalahan dalam kalimat, kelancaran dan

\footnotetext{
${ }^{1}$ Yohana Vita Desiani, Tingkat Kemampuan Berbicara Pembelajar Asing Level Beginner Menggunakan Tes Teknik Konstruktalog di Wisma Bahasa Yogyakarta (Yogyakarta: Tidak diterbitkan, 2017), h.viii

${ }^{2}$ Raden Yusuf Sidiq Budiawan dan Rukayati, "Kesalahan Bahasa dalam Praktik Berbicara Pemelajaran Bahasa Indonesia bagi Penutur Asing (BIPA) di Universitas PGRI Semarang Tahun 2018”, (Jurnal Kredo Vol. 2 No. 1 Oktober, 2018), h. 88-97
} 
senyapan, serta kenyaringan, (2) kesalahan dari segi kalimat dapat dibagi lagi menjadi tiga jenis, yakni kesalahan pilihan kata, kesalahan dalam penggunaan afiks, dan ketidakefektifan kalimat, dan (3) kesalahan berbahasa tersebut disebabkan oleh beberapa faktor, yakni faktor psikologis (gugup/ grogi), penguasaan topik, kurangnya kosa kata, pemilihan kata, pemahaman tata bahasa dan tata kalimat, dan interferensi bahasa ibu (B1).

Berdasarkan penelitian-penelitian tersebut, dapat disimpulkan bahwa mayoritas siswa asing (BIPA) mengalami kesulitan dalam melafalkan kosakata dalam bahasa Indonesia. Tentunya hal ini pun dirasakan oleh siswa BIPA di Davao, Filipina. Dengan demikian, diperlukan observasi lebih lanjut untuk menindaklanjuti hal tersebut demi tercapainya tujuan pembelajaran dan terealisasinya kompetensi siswa BIPA dalam berbicara terutama dalam melafalkan kosakata bahasa Indonesia dengan tepat.

Observasi dilakukan selama tiga (3) bulan, ditemukan kesalahan berulang yang dilakukan siswa saat melafalkan kata-kata yang mengandung vokal rangkap. Mereka sulit membedakan cara melafalkan diftong dan bukan diftong.

Diftong menurut Alwi dkk dapat didefinisikan sebagai berikut.

"Diftong merupakan gabungan bunyi dalam satu suku kata, tetapi yang digabungkan adalah vokal dengan $/ \mathrm{w} /$ atau $/ \mathrm{y} /{ }^{\prime \prime}{ }^{3}$.

Selain itu dalam Kamus Besar Bahasa Indonesia V luring dipaparkan bahwa diftong adalah "Bunyi vokal rangkap yang tergolong dalam satu suku kata (seperti ai dalam kata rantai, au dalam kata imbau)."

Diftong berbeda dengan vokal rangkap yang bukan diftong, contohnya: au pada kata bau tentunya bukan diftong karena tidak berada dalam satu suku kata, sehingga harus dilafalkan /bau/, bukan /baw/. Hal inilah yang menyulitkan siswa dalam membedakan pelafalan diftong dan bukan diftong karena mereka tidak mengetahui suku kata pada setiap kata dalam bahasa Indonesia.

Berdasarkan kajian di atas, peneliti tertarik mengkaji pelafalan kosa kata diftong dan bukan diftong siswa BIPA 1 (pemula) dalam pembelajaran berbicara di Davao City, Filipina.

\footnotetext{
${ }^{3}$ Hasan Alwi, dkk., Tata Bahasa Baku Bahasa Indonesia (Jakarta: Balai Pustaka, 2003), h. 27

${ }^{4}$ Badan Pengembangan dan Pembinaan Bahasa, Kemdikbud RI, Kamus Besar Bahasa Indonesia V 0.2.1 Beta (Jakarta: Kemdikbud, 2016)
} 


\section{Metode}

Objek penelitian ini adalah siswa BIPA 1 (pemula) di Davao City Filipina. Jumlah populasi penelitian sebanyak 22 orang, yakni staf KJRI sebanyak 5 orang, staf RDL Pharmaceutical sebanyak 7 orang, staf Presidential Security Guard sebanyak 4 orang, dan mahasiswa University of Southeastern Philippines sebanyak 6 orang (daftar nama terlampir).

Penentuan populasi diambil berdasarkan teori Arikunto5, yakni "Apabila kurang dari 100 lebih baik diambil semua hingga penelitiannya merupakan penelitian populasi. Jika jumlah subjeknya besar dapat diambil antara 10-15\% atau $20-55 \%$."

Metode yang digunakan dalam penelitian ini adalah metode deskriptif kualitatif, yakni penelitian yang dilakukan untuk mengetahui nilai variabel mandiri, baik satu variabel atau lebih (independen) tanpa membuat perbandingan, atau menghubungkan dengan variabel yang lain dengan data yang berbentuk kata, skema, atau gambar.

Teknik pengumpulan data yang digunakan adalah observasi dan wawancara. Observasi dilakukan secara langsung dengan cara mengamati pengucapan siswa saat melafalkan kata-kata bervokal rangkap di dalam kelas. Wawancara dilaksanakan setelah observasi. Wawancara dilakukan untuk memperkuat temuan hasil observasi. Adapun teknik wawancara yang dilakukan adalah siswa diarahkan untuk membaca nyaring kata-kata yang mengandung vokal rangkap, yang telah disediakan. Daftar kosakata diftong yang digunakan saat wawancara adalah silau, engkau, pulau, rantau, kalau, pantai, landai, pandai, sampai, dan andai. Sedangkan kosakata bukan diftong yang digunakan adalah bau, mau, audio, baur, baut, cintai, aib, kuasai, sertai, dan nyai.

Selain itu, dilakukan wawancara dengan dua orang narasumber, yakni Ibu Evelyn dan Ibu Jupi. Mereka adalah penutur asli Filipina namun sudah fasih dalam berbahasa Indonesia. Hal ini bertujuan mencari tahu penyebab kesalahan pelafalan siswa BIPA saat mengucapkan kata yang bervokal rangkap.

\footnotetext{
${ }^{5}$ Suharsimi Arikunto, Prosedur Penelitian Suatu Pendekatan Praktek, (Jakarta: Rineka Cipta, 2006), h. 112

${ }^{6}$ Sugiyono, Metode Penelitian Pendidikan; Pendekatan Kuantitatif dan R\&D (Bandung: Alfabeta, 2013), h. 11
} 


\section{Pembahasan}

Berdasarkan hasil observasi (dapat dilihat pada tabel 1 dan tabel 2) dan wawancara yang telah dilakukan, ditemukan kesalahan pelafalan bunyi diftong dan bukan diftong, yang akan dianalisis pada pembahasan ini.

Tabel 1. Temuan Penelitian (Pelafalan Diftong)

\begin{tabular}{|c|c|c|c|c|c|c|}
\hline No. & $\begin{array}{l}\text { Pelafalan } \\
\text { Diftong }\end{array}$ & Jumlah & $\begin{array}{l}\text { Persentase } \\
\text { (\%) }\end{array}$ & $\begin{array}{l}\text { Pelafalan } \\
\text { Diftong }\end{array}$ & Jumlah & Persentase (\%) \\
\hline 1 & {$[$ silAw $]$} & 20 & 91 & [sila.u] & 2 & 9 \\
\hline 2 & [enkAw] & 22 & 100 & [əңka.u] & 0 & 0 \\
\hline 3 & [pulAw] & 20 & 91 & [pula.u] & 2 & 9 \\
\hline 4 & [rañtAw] & 20 & 91 & [rAñta.u] & 2 & 9 \\
\hline 5 & [kalAw] & 20 & 91 & [kala.u] & 2 & 9 \\
\hline 6 & [pAñtAy] & 22 & 100 & [pAñta.i] & 0 & 0 \\
\hline 7 & [liAndAy] & 22 & 100 & [IAñda.i] & 0 & 0 \\
\hline 8 & [pAñdAy] & 22 & 100 & [pAñda.i] & 0 & 0 \\
\hline 9 & [sAmpAy] & 22 & 100 & [sAmpa.i] & 0 & 0 \\
\hline 10 & [añdAy] & 22 & 100 & [añda.i] & 0 & 0 \\
\hline Total & & 212 & 96 & Total & 8 & 4 \\
\hline
\end{tabular}

Tabel 2. Temuan Penelitian (Pelafalan Bukan Diftong)

\begin{tabular}{|c|c|c|c|c|c|c|}
\hline No. & $\begin{array}{l}\text { Pelafalan } \\
\text { Bukan } \\
\text { Diftong }\end{array}$ & Jumlah & $\begin{array}{l}\text { Persentase } \\
\text { (\%) }\end{array}$ & $\begin{array}{l}\text { Pelafalan } \\
\text { Bukan } \\
\text { Diftong }\end{array}$ & Jumlah & $\begin{array}{l}\text { Persentase } \\
\text { (\%) }\end{array}$ \\
\hline 1 & {$[\mathrm{bAw}]$} & 15 & 68 & [ba.u] & 7 & 32 \\
\hline 2 & {$[\mathrm{mAw}]$} & 15 & 68 & [ma.u] & 7 & 32 \\
\hline 3 & [awdio] & 22 & 100 & [a.udio] & 0 & 0 \\
\hline 4 & [bawUr] & 5 & 23 & [ba.ur] & 17 & 77 \\
\hline 5 & [bawUt] & 2 & 9 & [ba.ut] & 20 & 91 \\
\hline 6 & [cIñtay] & 22 & 100 & [cIñta.i] & 0 & 0 \\
\hline 7 & [eib] & 5 & 23 & [a.ib] & 17 & 77 \\
\hline 8 & [kuwasAy] & 21 & 95 & [kuwasa.i] & 1 & 5 \\
\hline 9 & [sərtAy] & 21 & 95 & [sərta.i] & 1 & 5 \\
\hline 10 & {$\left[{ }^{\prime} \mathrm{Ay}\right]$} & 20 & 91 & [ńa.i] & 2 & 9 \\
\hline Total & & 148 & 67 & Total & 72 & 33 \\
\hline
\end{tabular}

Pertama, kesalahan pelafalan diftong terdapat pada kata /silau/, /pulau/, /rantau/, dan /kalau/. Sebanyak 9\% siswa melafalkannya menjadi [sila.u], [pula.u], [rAñta.u], dan [kala.u], yang seharusnya dilafalkan [silAw], [pulAw], [rAñtAw], dan [kalAw]. Kedua, kesalahan pelafalan bukan diftong terdapat pada kata /bau/, /mau/, /audio/, /baur/, /baut/, /cintai/, /aib/, /kuasai/, /sertai/, dan /nyai/.

Bentuk kesalahan tersebut dijabarkan dalam temuan berikut ini. Sebanyak $68 \%$ melafalkan /bau/ menjadi [baw] yang seharusnya [bau], 68\% melafalkan /mau/ menjadi [maw] yang seharusnya [mau], 100\% melafalkan /audio/ menjadi [awdio] yang seharusnya [audIo], 23\% melafalkan /baur/ menjadi [bawUr] yang seharusnya [baur], 9\% melafalkan /baut/ menjadi [bawut] yang 
seharusnya [baut], 100\% melafalkan /cintai/ menjadi [cIñtAy] yang seharunsya [cIñtAi], 23\% melafalkan /aib/ menjadi [eib] yang seharusnya [aIb], 95\% melafalkan /kuasai/ menjadi [kuwasAy] yang seharusnya [kuwasAi], 95\% melafalkan /sertai/ menjadi [sərtay] yang seharusnya [sərtai], dan 91\% melafalkan /nyai/ menjadi [ńay] yang seharusnya [ńai].

Di luar temuan di atas, muncul temuan lainnya, yaitu beberapa siswa BIPA 1 melafalkan kosakata bukan diftong secara terpisah, terutama di silabel akhir kata, yakni pada kata /bau/, di mana 32\% melafalkan [ba.u] seharusnya [bau]. Kemudian untuk kata $/ \mathrm{mau} /, 32 \%$ melafalkan [ma.u] seharusnya [mau]. Sedangkan untuk kata /baur/, 77\% melafalkan [ba.ur] seharusnya [baur]. Dan untuk kata /baut/, 91\% melafalkan [ba.ut] seharusnya [baut]. Selanjutnya untuk kata /aib/, 77\% melafalkan [a.ib] seharusnya [aib]. Sementara untuk kata /kuasai/, 5\% melafalkan [kuasa.i] seharusnya [kuwasai]. Sedangkan untuk kata /sertai/, 5\% melafalkan [sərta.i] seharusnya [sərtai]. Dan terakhir untuk kata /nyai/, 9\% melafalkan [ń́.i/ seharusnya [ń́i].

Berdasarkan paparan tersebut, ditemukan adanya kekeliruan pelafalan vokal rangkap diftong dan bukan diftong. Secara keseluruhan, sebanyak 96\% melafalkan vokal rangkap diftong dengan benar dan $4 \%$ masih melafalkan salah. Sedangkan $67 \%$ melafalkan vokal rangkap bukan diftong menjadi diftong dan $33 \%$ melafalkan vokal rangkap secara terpisah (dibaca per huruf di silabel akhir).

Berdasarkan temuan di atas, kebingungan para siswa dalam membedakan diftong dan bukan diftong terlihat jelas, walaupun pada saat melafalkan diftong, siswa tidak terlalu banyak melakukan kesalahan pelafalan, yakni sebanyak $96 \%$ melafalkan benar dan $4 \%$ melafalkan salah. Berbeda halnya saat siswa melafalkan bukan diftong, 67\% melafalkannya menjadi diftong, yakni adanya perubahan bunyi yang seharusnya /au/ menjadi /aw/, /ai/ menjadi /ay/, contohnya pada kata/bau/ menjadi [baw], /mau/ menjadi [maw], /kuasai/ menjadi [kuasAy], /sertai/menjadi [sərtAy], dan /nyai/menjadi [ńay]. Selain itu, adapula 33\% yang dilafalkan secara terpisah (vokal dibaca satu per satu), yakni /bau/ menjadi [ba.u], /mau/ menjadi [ma.u], /baur/ menjadi [ba.ur], /baut/ menjadi [ba.ut], /aib/ menjadi [a.ib], /kuasai/ menjadi [kuwasa.i], /sertai/ menjadi [sərta.i], dan /nyai/ menjadi [ńa.i].

Kesalahan pelafalan tersebut disebabkan oleh tiga hal. Pertama, pengaruh bahasa Visaya, bahasa lokal di Davao City. Kedua, pengaruh bahasa Spanyol. Secara historis, Filipina telah dijajah oleh Bangsa Spanyol selama 300 tahun. Tentunya hal ini sangat berpengaruh pada eksistensi bahasa yang digunakan. 
Ketiga, terdapat alofon dalam vokal rangkap bahasa Indonesia, seperti /ai/ beralofon /ay/ pada kata/pantai/ dan /ai/ pada kata /sertai/, /au/ beralofon /aw/ pada kata /kalau/ dan /au/ pada kata /bau/. Menurut Ibu Evelyn dan Ibu Jupi (penutur jati bahasa Filipina namun sudah fasih berbahasa Indonesia), dalam bahasa Visaya tidak ada vokal rangkap, yang ada hanyalah bunyi /ay/, /iw/, dan law/. Bunyi-bunyi tersebut ditulis dengan <ay> dan <aw > bukan dengan <ai> ataupun <au>, contohnya /away/ yang berarti 'berkelahi', /bahay/ yang berarti 'rumah', /bayaw/ yang berarti 'adik/kakak ipar', dan /baliw/ yang berarti 'gila'. Berbeda halnya dengan bahasa Spanyol yang memiliki vokal rangkap, yakni /ao/ yang ditulis dengan <ao $>$ bukan <aw $>$ dan /ai/ yang ditulis dengan <ai $>$ bukan $<$ ay>, contohnya pada kata /mabait/ yang dibaca/maba.it/ yang berarti 'orang baik' dan /bao/ yang dibaca /ba.o/ yang berarti 'kura-kura'. Hal ini tentunya sangat berbeda dengan penulisan dan pelafalan vokal rangkap dalam bahasa Indonesia, seperti vokal rangkap /au/ ditulis dengan <au> namun pada saat dilafalkan bisa menjadi [aw] pada kata/pulau/ dan menjadi [au] pada kata /bau/. Hal inilah yang menyulitkan siswa saat melafalkan vokal rangkap dalam bahasa Indonesia karena huruf yang tertulis tidak sesuai dengan bunyi saat dilafalkan (terdapat alofon).

Kesalahan pelafalan kosakata tersebut, tentunya harus ditindaklanjuti agar tujuan pembelajaran terutama untuk kompetensi berbicara dapat tercapai secara maksimal. Tindak lanjut yang dapat dilakukan untuk masalah ini adalah melalui tiga cara. Pertama, dalam pembelajaran berbicara, digunakan teknik ucap silabel. Kedua, digunakan teknik ucap - tiru. Ketiga, digunakan teknik ucap ulang. Teknik ucap - silabel dapat membantu siswa mengetahui pemenggalan suku kata dalam kata yang dilafalkan, sehingga kekeliruan pemisahan pelafalan dalam vokal rangkap dapat diminimalkan. Teknik ucap - tiru membantu siswa dalam melafalkan kata dengan benar, dan teknik ucap - ulang membantu siswa dalam mengingat dan memfasihkan pelafalan. Ketiga cara ini telah dilakukan dan berhasil dalam memperbaiki kesalahan pelafalan dalam vokal rangkap bahasa Indonesia.

\section{Penutup}

Berdasarkan pembahasan di atas, dapat disimpulkan bahwa terdapat pengaruh bahasa Visaya terhadap siswa BIPA 1 yang melafalkan bukan diftong menjadi diftong, dan pengaruh bahasa Spanyol terhadap siswa BIPA 1 yang melafalkan vokal rangkap secara terpisah (dibaca satu per satu huruf dalam vokal rangkap pada silabel akhir). Selain itu, terdapat alofon dalam vokal rangkap 
bahasa Indonesia, sehingga semakin menyulitkan siswa dalam membedakan vokal rangkap pada diftong dan bukan diftong. Namun demikian, kesalahan pelafalan yang dilakukan siswa BIPA sangat lumrah terjadi, mengingat sistem bunyi dalam setiap bahasa memiliki karakteristik tersendiri.

Penelitian ini masih memiliki keterbatasan terutama dalam hal waktu penelitian dan jumlah objek penelitian. Keterbatasan waktu mengakibatkan kurangnya jumlah objek penelitian sehingga pembahasan belum dapat digeneralisasi secara menyeluruh. Hal yang dapat direkomendasikan guna perbaikan selanjutnya adalah penambahan waktu penelitian dengan harapan dapat menambah objek penelitian sehingga pembahasan dapat lebih menyeluruh. Selain itu, untuk pembelajaran, pengajar sebaiknya tidak menyalahkan ataupun menertawakan kesalahan yang dilakukan siswa BIPA karena hal ini dapat menciutkan motivasi belajar. Selain itu, pengajar sebaiknya terus berusaha mencari solusi inovatif untuk meminimalkan kesalahan-kesalahan yang dilakukan siswa BIPA.

Terdapat tiga implikasi dalam riset ini. Pertama, kesulitan siswa dalam membedakan vokal rangkap berupa diftong dan bukan diftong dapat diminimalkan. Kedua, kekeliruan pelafalan vokal rangkap bahasa Indonesia dapat diatasi. Ketiga, solusi yang diberikan dapat menjadi alternatif bagi guru BIPA yang mengalami kasus yang sama.

\section{Ucapan Terima Kasih}

Terima kasih saya sampaikan kepada Pusat Pengembangan dan Strategi Diplomasi Kebahasaan (PPSDK) Sentul-Bogor, terutama kepada Prof. Emi Emilia selaku Kepala PPSDK yang telah memberikan kesempatan kepada saya untuk mengajarkan bahasa Indonesia di Davao City - Filipina. Selain itu, terima kasih pada Sekolah Indonesia Davao (SID), terutama kepada Ibu Evelyn dan Ibu Juvi selaku guru asal Filipina yang mengajar di SID, yang telah banyak membantu saya dalam proses pengambilan dan pengolahan data penelitian. Terima kasih juga kepada Konjen KJRI Davao City, Bapak Berlian Napitupulu, Kepala Sekolah SID, Bapak Agus, M.Pd., Pensosbud, Ibu Endah Yuliarti, yang telah berkenan memberikan izin kepada saya untuk melakukan penelitian terhadap siswa BIPA 1 di Davao City-Filipina. Terima kasih juga kepada seluruh siswa BIPA 1 yang telah berkenan meluangkan waktunya untuk penelitian ini. Terima kasih pula kepada Jurnal Dialektika Universitas Islam Negeri Jakarta Syarif Hidayatullah yang telah berkenan menerima dan mempublikasikan hasil penelitian saya selama mengajar BIPA di Davao City - 
Filipina. Tidak lupa kepada suami, Asep Dany Rachman dan anak-anakku, Salim Syauqi Rachman dan Tata Tauhid Rahman yang rela ditinggalkan selama empat bulan dan selalu memberikan motivasi saat penelitian ini berlangsung. Terima kasih untuk kedua orang tua saya, Djahidin Suryana dan Sri Heryati serta kedua mertua saya, Atang Mustafa dan Enok Rosmanah yang selalu mendoakan kesuksesan untuk saya. Terakhir, terima kasih kepada seluruh teman-teman saya yang tidak dapat disebutkan satu per satu.

\section{Daftar Pustaka}

Alwi, Hasan dkk. 2003. Tata Bahasa Baku Bahasa Indonesia. Jakarta: Balai Pustaka.

Arikunto, Suharsimi. 2006. Prosedur Penelitian Suatu Pendekatan Praktek. Jakarta: Rineka Cipta.

Badan Pengembangan dan Pembinaan Bahasa, Kemdikbud RI. 2016. Kamus Besar Bahasa Indonesia V 0.2.1 Beta. Jakarta: Kemdikbud.

Budiawan, Raden Yusuf Sidiq dan Rukayati. 2018. "Kesalahan Bahasa dalam Praktik Berbicara Pemelajaran Bahasa Indonesia bagi Penutur Asing (BIPA) di Universitas PGRI Semarang Tahun 2018”. Jurnal Kredo Vol. 2 No. 1 Oktober: 88-97.

Desiani, Yohana Vita. 2017. Tingkat Kemampuan Berbicara Pembelajar Asing Level Beginner Menggunakan Tes Teknik Konstruktalog di Wisma Bahasa Yogyakarta. Yogyakarta: Tidak diterbitkan.

H.P., Ahmad \& Alek Abdullah. 2009. Linguistik Umum: Sebuah Ancangan Awal Memahami Ilmu Bahasa. Jakarta: FITK Press UIN Syarif Hidayatullah.

Kusmiatin, Arik. 2016. Mengenal BIPA (Bahasa Indonesia bagi Penutur Asing) dan Pembelajarannya. Yogyakarta: K-Media.

Sugiyono. 2013. Metode Penelitian Pendidikan; Pendekatan Kuantitatif dan R\&D. Bandung: Al-Fabeta. 